УДК 913.1

\title{
О.Д. Федченко
}

\section{БАЛТСКАЯ ГИДРОНИМИЯ КАМСКО-ВЯТСКОГО РЕГИОНА}

Статья посвящена лингвистическому анализу гидронимов Кировской области и Удмуртии. Рассматривается происхождение названий значительных (протяженностью около 100 км и более) рек Камско-Вятского региона. Произведена систематизация гидронимов, получивших имя в балтской языковой среде. Названия рек имеют этимологию, родственную таким понятиям, как река, русло, поток, течение. Предложенная статья дает возможность уточнить археологические и исторические аспекты жизни древних людей в Поволжье и Прикамье. Подтверждается мнение, что племена боевых топоров были местным населением на территории Камско-Вятского региона до появления там финноугорских народов.

Ключевые слова: гидронимы, этимология, Вятка, балтизмы, Киров, Кама, Волга.

DOI: 10.35634/2412-9534-2019-29-6-924-932

Исследователи, изучая гидронимы Поволжья, Северо-Запада Руси, часто вынуждены признавать, что этимология названий не ясна и не может быть объяснена из финно-угорских языков. Ученые вынуждены предлагать варианты из неких «древних» (пра-, до-, около-) исчезнувших языков.

В то же время, в 30-е гг. прошлого столетия академик А.И. Соболевский сделал следующий вывод: «Я ограничиваюсь сопоставлением данных в области названий рек и озер Поволжья, Прикамья и русского севера с данными названий на юге и в центре России. Исходный пункт моей работы предположение, что эти две группы названий родственны между собой и принадлежат одному языку индоевропейской семьи, который я пока, впредь до подыскания более подходящего термина, именую скифским» [15. С. 19].

Более определенно о языковой среде дофинноугорского субстрата высказался Б.А. Серебренников. В 1955-1957 гг. в своих работах он утверждал, что топонимика Волго-Окского междуречья при помощи финно-угорских языков необъяснима... население, оставившее эти названия, по своему языку было близко к балтийскому и территориально примыкало к балтам Верхнего Поднепровья [13. С. 83].

Б.А. Серебренников выявил соответствия между коми языком и каким-то неизвестным индоевропейским языком балтийского типа, что позволяет определить контакты пермских племен с древнебалтийскими [11. С. 9].

Еще М. Гимбутас отмечала, что фатьяновская культура распространилась в низовьях Камы, верховьях Вятки и даже в бассейне реки Белой, расположенных в современных Татарии и Башкирии [5. C. 38].

Таким образом, есть основания посмотреть на гидронимию Поволжья и Прикамья с позиций балтской языковой среды. При этом, древнее название реки должно соответствовать принципу «поток-движение-образ» [24], который позволяет выявить этимологию и определенную закономерность в региональной топономастике. В таком контексте изучим происхождение названий значительных (протяженностью около 100 км и более) рек Кировской области и Удмуртии.

Белая - правый приток Вятки. Этимология гидронима восходит к глаголу biẽlyti, -ija, значение которого сечь, хлестать (отмечаем присутствие глагола lupti, см. Лобань), косить (суетиться), бледнеть [30], что отлично характеризует извилистую реку, текущую по заболоченной местности. В литовской гидронимии встречаем однокоренные названия Bieliukas и другие (включая корень Bel-) [34. С. 65]. К рассмотренной корневой системе можно отнести многие гидронимы на территории европейской России (однако в данном вопросе стоит подходить осторожно, поскольку не все однокоренные гидронимы имеют одинаковое происхождение).

Боковая - левый приток реки Пижма. Этимология происходит из глагола bukúoti, -úoja, -ãvo бить, хлестать (mušti), толочь, толкать, шастать [30]. Литовским аналогом может выступать река Bikava и, вероятно, гидронимы с корнем Bak-/Buk- [34. С. 64].

Буй - приток Вятки. Исследователи предлагаю происхождение от финноугорского «вуйя» (речка, ручей), башкирского «буй» (долина реки) и марийского «вуй» (голова, головной). Между тем, этимология гидронима может быть связана с балтским глаголом bijóti, bìjo - бояться, вилять (петляет, 
как заяц - образ), поднимать [30]. При этом, индоевропейская основа bhei- указывает на первоначальное значение «бить, колоть» [17. Т. 1. С. 220; 28. С. 129-130]. В продолжение ряда К. Карулис ставит и bite - пчела, расширяя набор значений до «жалить, увиливать, махать». Гидронимы Bijotas, Bijunas и другие можно встретить в балтийском регионе [34. С. 63].

Вала - левый приток реки Кильмезь. Этимология гидронима может быть связана с глаголом veléti, -éja (vẽli) - омывать, хлестать, поглощать, раскачивать [30]. Названия рек с корнем Vel- широко представлены в балтийском регионе [34. С. 370-371).

Великая - правый приток реки Вятки. Этимологию, связывающую данный гидроним с древнерусским словом «великий» [12. С. 77], можно отнести лишь к огласовке первичного названия. Аналогичные имена имеют реки в Вологодской, Ленинградской, Нижегородской, Псковской областях, а также небольшие речушки, например, в Поднепровье - притоки рек Вопец, Ужа, Утвоха (бассейн Припяти) [9. С. 9, 16, 146]. Обстоятельный анализ представил А.Г. Манаков, хотя вывод так и не состоялся - то ли венеты, то ли славяне, то ли балты [8. С. 129-131]. Однако, в данном случае можно предположить, что этимология кроется в балтском глаголе vilkéti, viliki (-éja) (носить, истирать, расти, истекать [30]).

Ветлуга - левый приток Волги. Принятой считается версия происхождения названия от марийского «вутла», «вытла» в значении «многоводная» [14. С. 96]. Однако В.А. Никонов уточняет, что «без анализа форманта -уга эти домыслы имеют ценность не больше, чем легенда» [12. С. 82]. Впрочем, все это указывает на вторичную огласовку более древнего названия. Поэтому можно рассмотреть балтскую этимологию, которая нам предлагает дериватив глагола vyti - vytulúoti, -úoja - вить, двигать, течь [30]. Корень Vyt- достаточно распространен в балтийской гидронимии [34. С. 389-390].

Воя - левый приток Вятки. Этимология гидронима связана с балтским глаголом výti, vẽja (vija) - двигаться, виться (родственны также vajóti, -ója и vijóti, -ója) [30]. Реки Vaja, Vej, Vija и однокоренные встречаются в балтийском регионе [34. С. $360,370,380]$. Сюда же можно отнести и реку Вая приток Усты (бассейн Ветлуги).

Вя́тка - крупнейший правый приток Камы (бассейн Волги), от реки происходит название старинного города Вятка (ныне Киров - областной центр). Убедительной этимологии до сих пор не представлено. Удмуртскую (от ватка), славянскую (от вятше, вяче, вяще - большой), прафинноугорскую (уральскую) (от лексемы *vete - обозначение воды), прибалто-финскую (от vento - тихий, спокойный, глубокий) версии полностью разбил В.Л. Васильев [2. С. 28-29]. Одновременно исследователь предложил свою гипотезу, связав гидроним со славянским термином *větъka (ответвление чего-нибудь на местности), хотя и признал бессмысленность данного значения: «О конкретных причи-

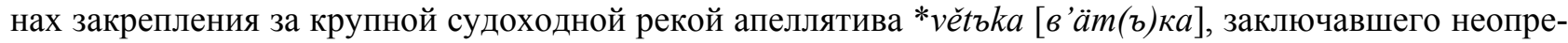
деленную метафорическую семантику ответвления (от основной реки, основного пути), остается лишь догадываться» [2. С. 33-34]. Действительно, предложенные В.Л. Васильевым объяснения указывают лишь на славянскую огласовку более древнего названия. Этимология гидронима может восходить к деривативу балтского глагола veti - vétyti, véčia - метаться, хлестать, поглощать, двигаться, разъединять [30]. Отметим, что в данном случае определяющими выступают глаголы, которые присутствуют не только в объяснении этимологии многих гидронимов, но и сами являются основой для названия рек в других регионах: varinèti (Ворона, Воронеж), mušti (Мста), valgyti (Волга, Волхов). Выявленное значение соответствует реке с резкими изменениями направления течения, сильной извилистостью на всём протяжении со множеством рукавов и стариц. Аналогичную огласовку встречаем в названии реки Летка.

Иж (удмуртская Ой, татарская Иж) - правый приток Камы. Этимология гидронима может восходить к балтскому глаголу aižyti, aižo, связанному с рядом глаголов ižtti, ižýti [25. С. 46; 30. С. 228], со значением лущить, вырезать, хлестать, крошить (включая lupti, mušti) [30]. Однокоренные гидронимы на $I \check{z}$-/Ež- отмечаются в литовском регионе [34. С. 101, 133].

Ита (удмуртская Ыта, Ыты) - левый приток Лозы. Этимология гидронима может быть опреде-

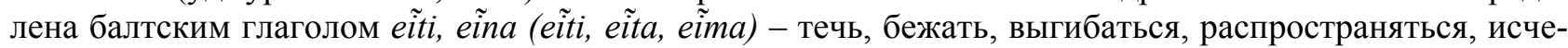
зать [30]. В Литве встречаем другие варианты в названиях рек - Eĩn-upis, Eĩmenys, Eĩsra [34. C. 100].

Кама - левый и самый крупный приток реки Волги. Исследователи объединяют общей этимологией названия Кама, Кемь и ряд однокоренных гидронимов. Как отмечает Е.М. Поспелов, наличие «местных терминов тув. хем «река», фин. kymi «поток» позволяет предполагать существование древнего географического термина со значением «река», некогда общего для ряда языков Евразии» [14. С. 182]. 
Сопоставляли также с фин. kerni - большая река, kymii течение, kemi - обваливающийся в воду речной берег, кар. kemi - сухое песчаное возвышенное место, удм. кам - река, течение [6. С. 82-83]. Следуя за мыслью Е.М. Поспелова, можно предположить, что этимология скрыта в едином корне kem- (kémti, kẽma) с разной степенью вокализма kam- (kamúoti) и kim- (kimti, -a). Приведенные глаголы объединены, по мнению В.Н. Топорова, «общим семантическим ядром, которое можно описать как наличие множественности мелких однородных элементов, «сдавливаемых» в нечто единое... которое может находиться в хаотичном движении, однако, не грозящем этой массе распадом... Еще одна особенность - заполненность и тенденция к росту, набуханию» [17. Т. 3. С. 189; 18. С. 149]. Не менее интересно и указание на типологическую аналогию с понятием «переть, продираться», которое мы часто встречаем в объяснении древнебалтских гидронимов. К данной корневой системе можно отнести также гидронимы Камен- и другие (однако в данном вопросе стоит подходить осторожно, поскольку не все однокоренные гидронимы имеют одинаковое происхождение).

Кильмезь (удмуртское Калмез) - левый приток Вятки. О. В. Смирнов предложил в основу названия финно-пермское *kilmä (külmä) - «холодный, студёный», марийское кыллме - «мёрзлый» [16. С. 21]. Однако исследований по температурному режиму рек не представлено, потому довольно трудно судить, как древние могли улавливать столь специфические особенности воды. Скорее, предложенное значение может указывать лишь на огласовку древнего названия реки. Этимология гидронима связана с глаголом kelmióti, -iója - двигаться, течь (eíti, см. Ита), брести, плестись [30]. Реки Kelmeja, Kelmai, Kelmyte и другие встречаются в балтийском регионе [33. С. 273; 34. С. 151].

Кобра - правый приток Вятки. Происхождение гидронима можно связать с древним глаголом kùbryti - долбить, раскалывать, вить, собирать, поглощать [30]. Однокоренные названия рек встречаем в Белоруссии (Кобринка, давшая название городу Кобрин, бассейн Западного Буга), Украине (Кобринка, приток Днепра), Ленинградской области (Кобринка, приток Суйды), в Литве (Kūbris)

Кокшага Большая - левый приток Волги. Достаточно распространеный гидронимический корень: реки Кокша протекают в Тверской, Рязанской, Кировской, Нижегородской, Омской областях, на Алтае, Кокшеньга - бассейн Северной Двины, Kàkšis, Kàkšinis - в Литве [34. C. 142]. Происхождение рассматриваемого названия можно связать с глаголом kakšéti, -éjo - стучать, трещать, разбивать, долбить (здесь же и kukšéti, -éjo) [30].

Коса - левый приток реки Чепца. Этимология гидронима связана с глаголом kušéti, kùša - двигаться, копошиться, обламывать, драть [30]. Реки Касинка, Кошна, Kuš-upis и другие встречаются в Поднепровье и Литве [19. С. 190-191; 34. С. 175].

Лекма - правый приток реки Летка, также имеются одноименные гидронимы - приток Вятки и приток Чепцы. Краеведы пытаются этимологически «породнить» Лекму и Летку, связывая их с индоевропейским корнем *lek- и семантикой «прыгающая», «скачущая», «летящая», «бегущая» [21. С. 33]. Впрочем, наличие других рек с названием Лекма, а также Лекта в днепровском бассейне, параллели которой ведут в балтийский регион [19. С. 192; 34. С. 185, 191], заставляют скептически относиться к гипотезе С. Ухова. В данном случае этимология связана с балтским глаголом likti (liêkti, liêkma, древнелитовская форма liekmi) - неспешно двигаться, пропадать, сновать, распространять, разъединять [32. C. 669-670; 30]. Реки Lik-upys и другие встречаем в литовской гидронимии [34. С. 191].

Летка - правый приток Вятки. Происхождение гидронима можно связать с балтским глаголом liẽsti, liěčia - касаться, двигать, наносить вред, драть [33. C. 351; 30].

Лобань - правый приток реки Кильмезь. Однокоренные гидронимы в Поднепровье (река Лобно) и в балтийском регионе приводит В.Н. Топоров [19. С. 192]. Тогда можно предположить, что этимология представлена производным от балтского глагола lupti- глаголом lùpinti, -ina, -ino - бить, хлестать, рвать, впитывать и т. д. [30]. В данном случае мы имеем в основе индоевропейский корневой дуплет leub-, leubh-, как реализацию сходного leu- с другим губным расширителем, что, собственно, и позволяет вслед за К. Бугом, который соотносил русский гидроним Лобно с балтским Lubina [17. T. 5. C. 365, 374-375], считать родственными названия Lub-/Lab-/Lob-/Lup-.

Лоза - левый приток Чепцы (см. Луза).

Лудяна - левый приток реки Вятки. Происхождение гидронима связано с глаголом lydenti, ena, значение которого определяется водным потоком (намокать, растворять, дождь, ливень и т. п.) [30]. Однокоренными названиями являются литовские реки Ludava (lydauti), Lyda, Lidenu и другие [34. C. 188-189]. 
Лýза - приток реки Юг (бассейн Северной Двины), протекает в Кировской и Вологодской областях, Республике Коми. В данном случае имеем иную степень вокализма от Лужа. Множество однокоренных гидронимов имеется в Поднепровье (включая реку Лыза) и Поочье. Встречаются Luž-upis и Lauž-upis и в литовской гидронимии [34. C. 184, 200]. Последние примеры указывают на балтскую основу - laužti, laužia, laužé; lū̌̌ti, lužo - расступаться, рвать(ся), прокладывать, обходить [27. С. 276, 297; 30]. Иная степень огласовки имеет река Лоза, левый приток Чепцы.

Лумпун - приток реки Кильмезь. Этимология названия связана с глаголом lumpinti, -ina, -ino трудно продвигаться, ползти (как червяк - образ) (сюда же с иным оттенком liumpinti, -ina, -ino трудно продвигаться, ползти, раскачиваться) [30]. Однокоренной гидроним Lum̃pe встречаем в Литве [34. C. 199].

Лупья - левый приток реки Кама (в бассейне Камы имеется три одноименных притока). По мнению исследователей, название происходит от коми-пермяцкого лоn - «древесный хлам», «валежник» или мансийского лупи, луn - «коряга» ( $я$ - «река») [10. С. 112]. Однако данный вывод указывает лишь на огласовку древнего гидронимы, этимология которого связана с балтским глаголом lūpéti, -éja (lupti), значение которого часто встречается в местных названиях (см. Белая, Лобань) - бить, хлестать, рвать, впитывать и т. д. [30].

Молома - правый приток Вятки. В литовской гидронимии встречаем название реки Malamoja, этимологию которой А. Ванагас связывает с глаголом málti (молоть, дробить, вить, двигать [27. C. 302; 30]) [34. С. 202]. Уточняющим семантику может служить глагол mulmyti, -ija - намокать, всхлипывать [30].

Немда - правый приток Пижмы; левый приток Вятки. Этимология не ясна, попытка переиначить на Невда [19. С. 198] все-таки малопродуктивна. В то же время В.Н. Топоров и О.Н. Трубачев правы, что «объяснение Фасмера <который предлагал связь с первонач. *Мъда "медленная река" [22. Т. 2. С. 588]> ... едва ли верно». Хотя мнение М. Фасмера о единстве гидронимов Нёмда и Немда необходимо признать. Тогда корень гидронимов своим происхождением обязан глаголу mùsti, mùdo кружить, нарушать, смешивать, теряться [30]. В Литве можно встретить достаточное количество гидронимов с корнем тѝs- [34. С. 222]. В бассейне Мсты имеется река Мда, в Поднепровье две реки с названием Немда, в бассейне Волги - одна. В нашем же случае первый элемент представлен префиксом $n u-$.

Нылга - правый приток реки Вала. Предлагается связать название реки с уральским *ńulkз, марийским нулго при удмуртским ньылnу, прапермским *ńul-pu - пихта [16. С. 13]. Однако, пихта это дерево, но не река. Исследователи безосновательно считают, что если гидроним Сосна, то это славянская огласовка более древнего названия; когда же встречаем пермскую пихту, то это признается оригинальным именем. Однако, такой подход указывает исключительно на имеющуюся огласовку более древнего гидронима. В таком случае интересным представляется наличие гидронимов Nylẽžeras, Nalija, Naul-upys и другие [34. C. 223, 225, 230]. При этом, отмечаем замечание А. Ванагаса о связи корней Nal-/Nol- c Nov-. Тогда можно вспомнить ранее рассмотренную этимологию гидронима Навля (приток Десны, бассейн Днепра) (24). Тогда было предложено происхождение от niauti (красть, тащить, бить, мучить, томить [30] - последние два значения как раз сближают с корнем nov-/nav-), с суффиксальным оформлением -ía-. Сам глагол имеет неясную этимологию. С одной стороны, его можно соотнести с индоевропейским корнем neu- (2. качаться, толкать [32. С. 767]), как и niausti [27. C. 334] (брести, понуря голову, неторопливо, извилисто течь [30]). Однако M. Villanueva Svensson разделяет niausti и niauti, предполагая связь последнего и индо-иранским корнем *nav- (двигаться) [35. C. 217]. Более предпочтительна параллель J. Pokorny, упоминающего литовский гидроним Nova при рассмотрении индоевропейского корня näus- (в широком смысле - желоб для скольжения, плавания судов [32. С. 755-756]). В продолжение данного ряда можно поставить и глагол naivaloti, -oja (который, возможно, и лег в основу рассматриваемого гидронима Нылга) с родственной семантикой изнурять, биться, двигаться [30].

Пижма - правый приток Вятки. Происхождение гидронима пытаются связать с пермским значением *požem (сосна) [1. С. 64-65] или с индоевропейским корнем то ли *pig- (маленький), то ли *peig- (пестрый) [21. С. 34]. Впрочем, представленные определения никак не соотносятся с географической характеристикой реки и могут указывать лишь на огласовку более древнего названия. Этимологию гидронима можно связать с глаголом peĩkti - рассекать, хлестать, точить, поглощать (выделяем в объяснении глагол kapoti, который «роднит» рассматриваемый гидроним с именем реки Чепца) 
[30]. В данном случае мы имеем архаичную форму, аналогичную конструкцию встречаем в гидрониме Лекма, - в прусском языке отмечается paikemmai [31. Т. 3. С. 210-211]. Рассмотренная этимология обеспечивает огласовку гидронимических корней Пежм-/Пыжм-. Однокоренные названия рек Реikвстречаются и в балтийском регионе [34. С. 252].

Порыш - левый приток Камы. Этимология восходит к глаголу ryžéti, rỹži (rỹža) с префиксом $p a-$ в значении увиливать, плохо двигаться (включая понятие at-likti, см. Лекма) [30]. В Литве встречаем гидроним Paryžis и другие однокоренные географические объекты [34. C. 245].

Уржумка - правый приток Вятки. Первоначальное название реки в различной огласовке звучало, как марийское - Вурзым, Вюрсум, славянское - Уржум, Оржум при впоследствии появившимся уменьшительным славянским суффиксом -ка [3], и исследователи связывают происхождение с финно-пермскими корнями вӥр, вир - лес и сём, сюм - речка, родник, ручей [4. С. 123]. Однако понятие «лес» не может быть характеристикой реки, русла, но может указывать на присутствующую огласовку древнего названия реки. Балтославянский корень *urg- со звукоподражающим значением «журчащая» предлагает краевед С. Ухов [21. С. 36]. Между тем, этимология гидронима может быть связана с балтским глаголом ver̃kti, -ia - лить, течь (слезы - образ) [30]. При этом, мы вновь сталкиваемся, вероятно, с архаичным (отмечается в древнепрусском языке) окончанием -mai [29. C. 104-105].

Холуница - левый приток Вятки. Этимология гидронима связана с балтским глаголом skaláuti, -áuja (skaláuna) - омывать потоком, а также уже известные mušti, perti [30]. В индоевропейском корне (s)kel- мы сталкиваемся с «гидронимическим» значением to cut [32. С. 923]. Также можно отметить вывод А.К. Шапошникова, что этимологическое $*_{s} k$ - в анлауте закономерно перешло в *x- перед гласными заднего ряда [25. С. 383]. Здесь же отметим иную огласовку данного глагола, дающего название притоку Мсты - реке Холова.

Чепца - левый приток Вятки. «Из данных удмуртского языка не удалось объяснить название Чепца» [21. С. 32]. Предлагая свою версию, С. Ухов обращается к индо-европейскому корню * $(s) k e p-$, пытаясь «воссоздать северо-великорусское чепец, в женском роде чепца - расщепленная». Однако, объяснение, что название характеризует лишь локальный участок реки - устье на основании наличия стариц, слишком неубедительно. Кроме того, отсыл к реке Чепец в Пермском крае, как ручей, противоречит водному объекту, протяженность которого более 60 км. Гидронимы с корнем Чап-/Чеп-/Кап/Кеп- также встречаются в Поднепровье и Поочье. При основе индоевропейского корня *(s)kep$/ *(s) k o p-$ происхождение названия Чепца может быть связана с деривативом балтского глагола kaptiглаголом kapséti, kàpsi (kàpsia) - двигать, постукивать, рубить, сечь, капать, прорывать [33. С. 254; 30]. В данном случае объясняется и русская, и удмурская огласовки Чо̄пца/Чепца/Чупчи.

Юг - составляющая Северной Двины. В качестве аналогии можно посмотреть на реку Юза в Вологодской области, приток Унжи, далее псковскую реку Уза (приток Шелони) и литовскую реку

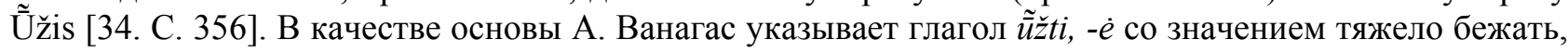
течь, распространяться, виться [30]. С данным глаголом связана и этимология гидронима Юзга -

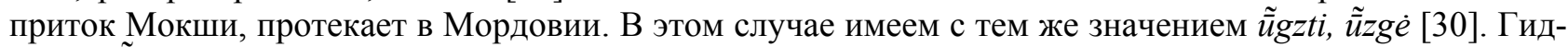
роним Ũ̈ge имеем на севере Шауляйского района Литвы [34. С. 352].

Ярань - правый приток Пижмы. Этимология гидронима не установлена, считает Е. М. Поспелов [14. С. 492]. Попытка связать происхождение с «марийским ер, йар (озеро) с суффиксом притяжательных прилагательных -Vн(ь), продуктивным в волжско-финских языках» [16. С. 12], малоперспективна в силу несоответствия характеристики водного объекта: река - не есть озеро. В то же время такой подход может указывать, что мы имеем дело с огласовкой древнего гидронима. В основе названия лежит архаичный глагол reneti, reni (создавать, прорубать борозду, желоб [30]) с распространенным префиксом $i$-. В Литве протекает река Rènelis, этимологию которой А. Ванагас сравнивает с литовским существительным renе́ (канавка, бороздка [30]) [34. С. 276] (хотя точнее было бы связать с однокоренным глаголом renéti).

Изучение гидронимов наглядно показало, что их значения взаимосвязаны и систематизированы. Кроме терминов, определяющих непосредственно движение воды (лить, течь, плескаться, хлестать), во многих названиях рек присутствуют такие понятия, как разрывать, раскалывать и т. п. В то же время эти глаголы определяют этимологию слова river (река) и его первоисточник - индоевропейский корень rei- [32. С. 857-859]. Можно посмотреть и на русло, которое наряду с глаголом течь, также сопоставляется с понятиями pыльь, pушumь, бить, ров и т. п. [26. Т. 2. С. 225], т. е. название гидронимов обозначает разлом, разрыв, углубление, исчезновение (под водой) земли и связь берегов 
водой. Подобное семантическое родство указывает на архаичность гидронимической системы и областей, и сопредельных территорий, на которых распространены балтские гидронимы. Все названия рек указывают на вид русла (трещину, рытвину, царапину, борозду в земле и т. п.) и соответствуют ранее выявленному принципу, отражающему «река/русло - поток - движение - образ» [24].

Этимология названий крупных рек Камско-Вятского бассейна имеет корни в балтской языковой среде, впоследствии подвергшихся финно-угорской и славянской огласовке. Отмечаем наличие достаточно древних, архаичных корневых форм, что позволяет объяснить распространение в северорусском ареале гидронимы с окончанием -ма. Разрешается противоречие, с которым столкнулись А.Н. Трубачев и В.Н. Топоров, указывавшие, что «неясность происхождения этого форманта усугубляется наличием широко распространенного за пределами Верхнего Поднепровья на севере и востоке...» [19. С. 158].

Таким образом, рассмотренные названия рек указывают на архаичную этимологию гидронимов, подтверждая предположение, что балтоязычные племена шли на территорию европейской России с северо-востока, направляясь далее в Европу. Как отмечает П. Н. Третьяков, в конце III - начале II тыс. до н. э. появились и стремительно распространились в Европе вплоть до Рейна, по Днепру, по Верхней и Средней Волге, в Причерноморье, на Балтике и в Южной Скандинавии племена шнуровой керамики или боевых топоров [20. С. 69]. Именно, эти племена, будучи балтоязычными, и стали предками германцев, балтов и славян. Отсюда и «германизмы», находимые лингвистами, в современных балтийских и славянских языках, тогда как все они являются лишь следствием развития балтского языка-предка. Например, древнерусский «князь» происходит не от германского, а от балтского kūningas (kūnùs, возвышенный, большой человек, столп). Корень kūn- вытекает из глагола - kauti (kauna), заключающем «военные» значения «рубить, резать, колотить» [23. С. 34], с древнебалтским суффиксом -ing [7, с. 104].

Этимология гидронимов не хуже генетики и археологии позволяет выявить миграционные потоки групп населения.

\section{СПИСОК ИСТОЧНИКОВ И ЛИТЕРАТУРЫ}

1. Белых С.К. Парамермяне на Вятке // Вестн. Удм. ун-та. Сер. История и филология. 2018. Т. 28, вып. 1. С. 60-69.

2. Васильев В.Л. Еще раз о происхождении названий реки Вятка и города Вятка (совр. Киров) // Вопросы ономастики. 2016. Т. 13, № 2. С. 23-39.

3. Ветлужских В.А. Основание города Уржума. [Электронный pecypc] URL: http://sudba.ucoz.net/publ/urzhum/ osnovanie goroda_urzhuma/39-1-0-89

4. Галкин И.С. Кто и почему так назвал: рассказы о географических названиях Марийского края. Йошкар-Ола: Маркнигоиздат, 1991. 158 с.

5. Гимбутас М. Балты. Люди янтарного моря. М.: Центрполиграф, 2004, 223 с.

6. Кузнецов А.В. Словарь гидронимов Вологодской области. Тотьма - Грязовец: Грязовецкая типография, 2010. 290 с., карты

7. Кузьменко Ю.К. Ранние германцы и их соседи: Лингвистика, археология, генетика / отв. ред. Н.Н. Казанский. СПб.: Нестор-История, 2011. 266 с.

8. Манаков А.Г. Псковско-новгородская топонимия в свете «теории формантов» (к дискуссии об этнической истории региона) // Псковский регионологический журнал. № 3. Псков: ПГПУ, 2006. С. 115-135

9. Маштаков П.Л. Список рек Днепровского бассейна. С картой и алфавитным указателем. СПб.: Б. и., 1913. 292 c.

10. Матвеев А.К. Географические названия Урала: краткий топоним. слов. / А. К. Матвеев. 2-е изд., перераб. и доп. Свердловск, 1987. 208 с.

11. Матвеев А.К. К проблеме дофинноугорского субстрата в севернорусской топонимике. // Вопросы топономастики, №1, 1962, с. 3-9

12. Никонов В.А. Краткий топонимический словарь. М.: Мысль, 1966. 509 с.

13. Откупщиков Ю.В. Древняя гидронимия в бассейне Оки. Балто-славянские исследования XVI. Cборник научных трудов. М.: Индрик, 2015. С. 83-114

14. Поспелов Е.М. Географические названия мира: Топонимический словарь: Ок. 5000 единиц / отв. ред. Р.А. Агеева. 2-е изд. М.: Русские словари; Астрель; АСТ, 2002. 512 с.

15. Серебренников Б.А. Волго-окская топонимика на территории Европейской части СССР. Вопросы языкознания, 1955, №6, стр. 19-31. 
16. Смирнов О.В. К вопросу о пермском топонимическом субстрате на территории Марий Эл и в бассейне среднего течения реки Вятки (в свете этнической интерпретации археологических культур). 2 // Вопр. ономастики. 2014. № 1 (16). С. 7-34.

17. Топоров В.Н. Прусский язык. Словарь. М.: Наука, 1975-1990. Т. 1-5.

18. Топоров В.Н. Из хеттско-лувийской этимологии: теофорное имя Kamrušepa // Этимология, 1983. М.: Наука, 1985. C. $146-160$.

19. Топоров В.Н., Трубачев О.Н. Лингвистический анализ гидронимов Верхнего Поднепровья. М.: Издательство AH CCCP, 1962. $271 \mathrm{c}$.

20. Третьяков П.Н. Финно-угры, балты и славяне на Днепре и Волге. М.; Л.: Наука, 1966, 347 с.

21. Ухов С. История Вятки как часть этнической истории восточной Европы. [Электронный pecypc] URL: http://glybrary.ru/rukopisi/history-vyatka/

22. Фасмер М. Этимологический словарь русского языка: в 4 т. М.: Прогресс, 1986.

23. Федченко О.Д. Днепр, «росские» и «славянские» пороги (этимология названий) // Актуальные вопросы филологических наук: материалы V Междунар. науч. конф. Казань: Бук, 2017. С. 30-36. [Электронный ресурс] URL: https://moluch.ru/conf/phil/archive/257/12841/

24. Федченко О.Д. Древние гидронимы и топонимы Брянской области // Вестник экспериментального образования. 2019. № 1. [Электронный ресурc]. URL: http://www.ppacademy.ru/wp-content/uploads/2019/03/118.pdf

25. Шапошников А.К. Проблема праславянских соответствий $\mathrm{x} \sim \mathrm{sk} \sim$ šč // Труды Института русского языка им. В.В. Виноградова. Вып. 4. М., 2015. с. 364-390

26. Этимологический словарь русского языка: в 3 т.. / составил А. Преображенский. М.: Тип. Г. Лисснера и Д. Собко, 1910-1914. В 3 томах.

27. Derksen R. Etymological dictionary of the Baltic inherited lexicon. Brill. Leiden·Boston, 2015. 684 p.

28. Karulis K. Latviešu etimologiijas vārdnīca, Avots, Rīga 2002, 670 p.

29. Kortlandt F. The formation of the Old Prussian present tense // Baltistica XXII(2) 1987, pp. 104-111.

30. Lietuvių kalbos žodynas (t. I-XX, 1941-2002). Vilnius: Lietuvių kalbos institutas, 2005. [Электронный ресурс] URL: http://LKZ.lt/

31. Mažiulis V. Prūsų kalbos etimologijos žodynas. Vilnius: Mokslas, Mokslo ir enciklopedijų leidykla, T. 1-4, 19881997.

32. Pokorny J. Indogermanisches Etymologisches Wörterbuch, Bern \& München, 1959. 1183 p.

33. Smoczyński W. Słownik etymologiczny języka litewskiego (Lietuvių kalbos etimologinis žodynas). Vilnius: Vilniaus universitetas, 2007. $823 \mathrm{p}$.

34. Vanagas A. Lietuvių hidronimų etimologinis žodynas. ("Etymological Dictionary of Lithuanian Hydronyms"). Vilnius: Mokslas, 1981. 408 p.

35. Villanueva Svensson M. The origin of the type Lith. bliáuti, bliáuja, Latv. bḷaût, bl̦aûju in a Balto-Slavic perspective // Baltistica XLVI(2) 2012, Vilnius: Vilnius University Press. pp. 201-223.

Поступила в редакцию 05.06.2019

Федченко Олег Дмитриевич, независимый исследователь

Брянск, Россия

SPIN-код: 2825-0575

E-mail: vukby@yandex.ru

\section{O.D. Fedchenko \\ BALTIC HYDRONYMIA OF THE KAMA-VYATKA REGION}

DOI: $10.35634 / 2412-9534-2019-29-6-924-932$

The article is devoted to the linguistic analysis of hydronyms of the Kirov region and Udmurtia. The origin of the names of large rivers (about $100 \mathrm{~km}$ and more in length) of the Kama-Vyatka region is considered. The systematization of hydronyms, received their names in the Baltic language environment, is carried out. The names of the rivers have an etymology related to such concepts as the river, the channel, the flow. The proposed article provides an opportunity to clarify the archaeological and historical aspects of the life of ancient people in the Volga region and the Kama region. The opinion is confirmed that the tribes of battle axes were the local population in the territory of the Kama-Vyatka region before the appearance of the Finno-Ugric peoples there.

Keywords: hydronyms, etymology, Vyatka, baltisms, Kirov, Kama, Volga. 


\section{REFERENCES}

1. Belykh S.K. Paramermiane na Viatke [Paramermyane on Vyatka]. Vestnik Udmurtskogo universiteta. Seriia Istoriia i filologiia [Bulletin of Udmurt University. Series History and Philology]. 2018, vol. 28, no. 1, pp. 60-69.

2. Vasil'ev V.L. O probleme drevnebaltiiskogo toponimicheskogo naslediia na Russkom Severo-Zapade [About the problem of ancient Baltic toponymic heritage in the Russian North-West]. Voprosy iazykoznaniia [Questions of linguistics]. 2008, no. 3. pp. 76-94

3. Vetluzhskih V.A. Osnovanie goroda Urzhuma [Foundation of the city of Urzhum]. (Rules for the Citing of Sources) Available at: http://sudba.ucoz.net/publ/urzhum/osnovanie_goroda_urzhuma/39-1-0-89

4. Galkin I.S. Kto i pochemu tak nazval: rasskazy o geograficheskih nazvanijah Marijskogo kraja [Who and why so called: the stories about the geographical names of the Mari Territory]. Joshkar-Ola: Marknigoizdat, 1991. 158 p.

5. Gimbutas M. Balty. Ljudi jantarnogo morja [Balty. Amber Sea people]. M.: Centrpoligraf, 2004, 223 s.

6. Kuznecov A.V. Slovar' gidronimov Vologodskoi oblasti [Dictionary of hydronyms of the Vologda region]. Tot'ma Griazovets: Griazovetskaia tipografiia, 2010. 290 p., karty

7. Kuz'menko Ju.K. Rannie germancy i ih sosedi: Lingvistika, arheologija, genetika [Early Germans and their neighbors: Linguistics, archeology, genetics] /otv. redaktor N. N. Kazanskij. SPb.: Nestor-Istorija, 2011. 266 p.

8. Manakov A.G. Pskovsko-novgorodskaja toponimija v svete «teorii formantov» (k diskussii ob jetnicheskoj istorii regiona) [Pskov-Novgorod toponymy in the light of the "theory of formants" (to the discussion about the ethnic history of the region)] Pskovskij regionologicheskij zhurnal. No. 3. Pskov: PGPU, 2006. p. 115-135

9. Mashtakov P.L. Spisok rek Dneprovskogo bassejna. S kartoj i alfavitnym ukazatelem. SPb.: B. i., 1913. 292 s.

10. Matveev A.K. Geograficheskie nazvaniia Urala: Toponimicheskii slovar' [Geographic Ural names toponymic dictionary]. Ekaterinburg: Sokrat, 2008. 352 p.

11. Matveev A.K. K probleme dofinnougorskogo substrata $\mathrm{v}$ severnorusskoi toponimike [On the problem of the Dofinno-Ugric substrate in North Russian toponymy]. Voprosy toponomastiki [Questions of toponomastiki], 1962, no. 1, pp. 3-9.

12. Nikonov V.A. Kratkii toponimicheskii slovar' [A brief toponymic dictionary]. Moskow: Mysl', 1966. 509 p.

13. Otkupshhikov Ju. V. Drevniaia gidronimiia v basseine Oki [Ancient hydronymy in the Oka basin]. Balto-slavianskie issledovaniia XVI. Sbornik nauchnykh trudov [Balto-Slavic Studies XVI. Collection of scientific papers]. Moskow: Izdatel'stvo "Indrik", 2015. pp. 83-114

14. Pospelov E.M. Geograficheskie nazvaniia mira: Toponimicheskii slovar' [Geographic names of the world: Toponymic dictionary]. Moskow: Russkie slovari; Astrel'; AST, 2002. 512 p.

15. Serebrennikov B.A. Volgo-okskaja toponimika na territorii Evropejskoj chasti SSSR [Volgo-Oka toponymy on the territory European part of the USSR]. Voprosy jazykoznanija, 1955, no. 6, pp. 19-31.

16. Smirnov O.V. K voprosu o permskom toponimicheskom substrate na territorii Marij Jel i v bassejne srednego techenija reki Vjatki (v svete jetnicheskoj interpretacii arheologicheskih kul'tur). 2 [On the Permian toponymic substrate in the territory of Mari El and in the basin of the middle course of the Vyatka River (in the light of the ethnic interpretation of archaeological cultures) ]. Voprosy onomastiki. 2014, no. 1 (16). p. 7-34.

17. Toporov V.N. Prusskii iazyk. Slovar' [The Prussian language. Vocabulary]. Moskow: Izdatel'stvo "Nauka", $1975-$ 1990. vol. 1-5.

18. Toporov V.N. Iz hettsko-luvijskoj jetimologii: teofornoe imja Kamrušepa [From the Hittite-Luvian etymology: the teophoric name Kamrušepa]. Jetimologija, 1983. M.: Nauka, 1985. p. 146-160.

19. Toporov V.N., Trubachev O.N. Lingvisticheskij analiz gidronimov Verxnego Podneprov`ya [Linguistic analysis of hydronyms of the Upper Dnieper region]. M.: Izdatel'stvo AN SSSR, 1962. $271 \mathrm{p}$.

20. Tret'jakov P.N. Finno-ugry, balty $i$ slaviane na Dnepre $i$ Volge [Finno-Ugrians, Balts and Slavs on the Dnieper and the Volga]. Moskva-Leningrad. «Nauka», 1966, 347 p.

21. Fasmer M. Jetimologicheskij slovar' russkogo jazyka [Etymological dictionary of the Russian language]. M.: "Progress", 1986, v 4 tomah.

22. Fedchenko O.D. Dnepr, «rosskie» i «slavjanskie» porogi (jetimologija nazvanij) [Dnepr, "Russian" and "Slavic" rapids (etymology of names)]. Aktual'nye voprosy filologicheskih nauk: materialy V Mezhdunar. nauch. konf. Kazan': Buk, 2017. p. 30-36. [Jelektronnyj resurs] URL: https://moluch.ru/conf/phil/archive/257/12841/

23. Fedchenko O.D. Drevnie gidronimy i toponimy Brianskoi oblasti [Ancient Hydronyms and Toponyms of the Bryansk Region]. Vestnik eksperimental'nogo obrazovaniia [Bulletin of experimental education]. 2019, no. 1. (Rules for the Citing of Sources) Available at: http://www.ppacademy.ru/wp-content/uploads/2019/03/118.pdf

24. Shaposhnikov A.K. Problema praslavjanskih sootvetstvij $\mathrm{x} \sim$ sk $\sim$ šč [The problem of pre-Slavic correspondences $\mathrm{x}$ $\sim$ sk $\sim$ šč]. Trudy Instituta russkogo jazyka im. V.V. Vinogradova. Vol. 4. M., 2015. p. 364-390

25. Jetimologicheskij slovar' russkogo jazyka [Etymological dictionary of the Russian language]. Sostavil A. Preobrazhenskij. M.: Tip. G. Lissnera i D. Sobko, 1910-1914. V 3 tomah.

26. Derksen R. Etymological dictionary of the Baltic inherited lexicon. Brill. Leiden•Boston, 2015. 684 p.

27. Karulis K. Latviešu etimologijas vārdnīca, Avots, Rīga 2002, 670 p.

28. Kortlandt F. The formation of the Old Prussian present tense. Baltistica XXII(2) 1987, pp. 104-111. 
29. Lietuvių kalbos žodynas (t. I-XX, 1941-2002). Vilnius: Lietuvių kalbos institutas, 2005. no. 1. (Rules for the Citing of Sources) Available at: http://LKZ.lt/

30. Mažiulis V. Prūsų kalbos etimologijos žodynas. Vilnius: Mokslas, Mokslo ir enciklopedijų leidykla, T. 1-4, 19881997.

31. Pokorny J. Indogermanisches Etymologisches Wörterbuch, Bern \& München, 1959. 1183 p.

32. Smoczyński W. Słownik etymologiczny języka litewskiego (Lietuvių kalbos etimologinis žodynas). Vilnius: Vilniaus universitetas, 2007. $823 \mathrm{p}$.

33. Vanagas A. Lietuviu hidronimu etimologinis žodynas. ("Etymological Dictionary of Lithuanian Hydronyms"). Vilnius, "Mokslas", 1981. 408 p.

34. Villanueva Svensson M. The origin of the type Lith. bliáuti, bliáuja, Latv. bḷaût, bḷaûju in a Balto-Slavic perspective. Baltistica XLVI(2) 2012, Vilnius: Vilnius University Press. pp. 201-223.

Received 05.06.2019

Fedchenko O.D., independent researcher

Russia, Bryansk

SPIN-код: 2825-0575

E-mail: vukby@yandex.ru 